\title{
$1: 233007606-233039037$
}

National Cancer Institute

\section{Source}

National Cancer Institute. 1:233007606-233039037. NCI Thesaurus. Code C44978.

Physical location of LGALS8_Gene 